\title{
Correction to: Treatment of Excessive Daytime Sleepiness in Patients with Narcolepsy
}

\section{Laura Pérez-Carbonell, MD}

\section{Address}

Sleep Disorders Centre, Guy's and St Thomas' NHS Foundation Trust, 18-20 Newcomen St, London, SE1 1UL, UK

Email: laurapcarbonell@gmail.com

\section{Published online: 28 November 2019}

(C) Springer Science+Business Media, LLC, part of Springer Nature 2019

The online version of the original article can be found at https://doi.org/10.1007/s11940-019-0595-9

Correction to: Curr Treat Options Neurol (2019) 21: 57

https://doi.org/10.1007/s11940-019-0595-9

The correct spelling of the author should be listed as Laura Pérez-Carbonell, MD as shown above.

The original article has been corrected.

\section{Publisher's Note}

Springer Nature remains neutral with regard to jurisdictional claims in published maps and institutional affiliations. 